\title{
Reaching out to students
}

\section{Planning a library fair}

by Diane d'Almeida

$I^{\prime}$ n the beginning of the fall 1999 semester at the Massachusetts Institute of Technology (MIT), we held a library fair at the Dewey Library (the Management and Social Sciences Library that serves the Sloan School).

The academic year was about to start and we wanted to reach out to students before they got so caught up in their course work that they would have no free time to learn about the library's resources. Not only did we want to advertise our presence, our products, and our services to the student body, but we wanted to lift our somewhat sagging morale as well.

In this essay, I will explain how we achieved these goals and managed a very successful outreach to the small but busy community of local merchants of Kendall Square, Cambridge. Expectations of our outreach attempt were not only met, but, in fact, surpassed anything any of us had expected.

\section{Planning the fair}

Preparation for the fair began in July 1999 Our weekly staff meetings included 15 minute updates of our progress. We divided our tasks into several categories: how to market our products (databases, OPAC, print sources, library services); games to guarantee participation of the student com- munity; public relations; decorations; physical set-up of the library during the fair; and staff recruitment. Colleagues volunteered to take on the duties of heading task forces.

Libraries are notoriously famous for being short-staffed. Ours was no exception. However, it was summer and the staff was able to work steadily on this project. Our goal was to get people into the library, give them an idea of what rich materials we had, and have them leave the library with a positive feeling.

My idea of the marketing project for Dewey Library was not original, but it was new to the MIT community. Staff got on the bandwagon once it was clear what we were planning. Librarians and non-professionals were genuinely enthusiastic about boosting our image on the MIT campus, and wanted to have fun doing it.

My surprise during this effort was not at the reaction of the staff, but at the enthusiastic reaction of our local merchant community. I did not know that there would be so many merchants to jump at the idea of contributing goods and services to our fair. They were happy to do it and surprised to learn that there was a library around the corner where they could go to read the newspaper anytime.

\section{About the author}


I also had not expected the pure joy that showed on the faces of many MBA Sloan School students as they appeared after the fair with the magic stubs-winners of coupons ranging from $\$ 10$ to $\$ 100$ to local food establishments or elsewhere.

\section{Devising games and raffles}

To get them into the library, we devised a game/raffle plan that would require their physical presence in Dewey. Food and prizes were the way to go. Lining up raffle prizes turned out to be the most time-consuming feature of the library fair and the most successful. I made an initial list of 20-30 establishments in the vicinity of MIT-from banks, to cinemas, to restaurants, to health clubs. Although merchants were very willing to give, they required time, daily calls, visits, official letters, and faxes. Eventually, promised gifts began to arrive, and I knew we were in business.

The top prize offered by a local bank was a $\$ 100$ savings certificate; a healthclub contributed monthly passes; restaurants offered coupons for $\$ 5$ to $\$ 75$ coupons; and bookstores gave multiple certificates. Our total number of prizes was more than 100 . But the $\$ 100$ certificate deserved a raffle of its own, so we created a special quiz.

\section{Demonstrations at the fair}

Once the prizes were guaranteed, we focused on how we could best demonstrate our products and market our services to the Fair participants. It is not uncommon for academic patrons to be unaware of the rich databases available to them. New students, in particular, are not familiar with our full-text sources. MIT attracts a large foreign student population. Many of these new students are astounded when they learn that the databases (of which there are well over 100 at MIT) are available for free. We wanted to offer short and informative sessions on particular databases, library catalog, and library services. A tour of the library was also available. We set up Information Stations inside the library, manned by library staff.

The most efficient way to guarantee that people visited these information stations was to require that anyone wishing to enter the raffle must first visit an information station and have his or her voucher signed.

\section{The library fair put Dewey on the \\ map-for students and for the \\ local business community.}

Only then could he/she deposit the vouchers outside in the boxes. Raffle drawings were held every hour, and winners were notified immediately. All vouchers were of equal value. All prizes were not.

We had well over 300 people visit our booths from 10 a.m. to 3 p.m. that day. The date was ideal-students were back, had already registered, but had not started any routine yet. We hung balloons and a banner on the patio to attract as much attention as we could. Staff all wore t-shirts, printed (in red) with our names, Dewey Library, and a logo. The table outside, full of handouts of information on our electronic sources and other materials, held the raffle boxes and small giveaways from vendors. We spoke to as many passing people as we could and encouraged them to come into the library.

The library fair put Dewey on the mapfor students and for the local business community. There were more than 100 happy prizewinners, many of whom learned much about our resources. We felt we were 100\% successful in creating an image of the Dewey library as a place for information, a receptive and welcoming staff, and fun.

People like contests and they are delighted when they win. The local businesses in Kendall Square, Cambridge, make their living off the students of MIT. They are grateful to the institute, and enjoy the opportunity to give something back to the community. By tapping into these groups, we were able to promote our library and do something fun for our patrons and for ourselves.

In closing, I must tell the story of one winner. An international student who had arrived in the United States the previous month, was notified of his prize. When he came in to claim it, and I asked him what he had won, he said, ". . . something to do with hospitals." I thought hard but could not remember a hospital that had donated a prize. Upon looking it up, it seemed he'd won a $\$ 10$ certificate to Au Bon Pain, a local bakery. 